\title{
Brewery Spent Grain: Chemical Characteristics and utilization as an Enzyme Substrate
}

\author{
Khidzir K. M. ${ }^{1}$, Noorlidah Abdullah ${ }^{2}$ and Agamuthu P. ${ }^{3 *}$
}

${ }^{1}$ Solid Waste Laboratory, Institute of Biological Sciences, Faculty of Science, University of Malaya, 50603 Kuala Lumpur, Malaysia. ${ }^{2}$ Division of Environmental Management, Institute of Biological Sciences, Faculty of Science, University of Malaya, 50603 Kuala Lumpur, Malaysia. ${ }^{3}$ Division of Biotechnology, Institute of Biological Sciences, Faculty of Science, University of Malaya, 50603 Kuala Lumpur, Malaysia*agamuthu@um.edu.my (corresponding author)

Received on $21^{\text {st }}$ May 2009, accepted in revised form $15^{\text {th }}$ March 2010.

\begin{abstract}
Grains in a brewery that have been removed of their sugar content is classified as a byproduct known as spent grain. It is a low-cost material and is available year-round. In Malaysia, approximately $15 \%$ of brewery spent grain (BSG) that is produced is salvaged and sold as feedstock supplement, while the remainder is discarded in landfills. This is a waste of a potentially useful resource. The chemical composition of fresh BSG was studied. Nine species of fungi were individually inoculated onto sterile BSG and solid state fermentation occurred without chemical adjustment or supplementation. Activity of laccase, lignin peroxidase, xylanase, amylase, carboxymethyl cellulase, protease and tannase was assayed. BSG consists of lignin and cellulose. High enzyme activity of laccase was shown by Pleurotus sajor-caju, Penicillium chrysogenum, and Aspergillus niger. This study is possibly the first to report laccase activity by solid state fermentation of spent grain.
\end{abstract}

(Keywords: Solid state fermentation; waste reutilization; brewery spent grain; hydrolytic enzymes; fungi; sustainable management)

\section{INTRODUCTION}

Solid state fermentation (SSF) is the growth of microorganisms on a natural or man-made inert solid substrate [1] with sufficient moisture in the system to support the metabolism of the process microorganism [2]. Most of the moisture is absorbed within substrate particles while the space between substrate particles is filled with gas [3]. Due to its simplicity, low-cost, lowtechnical/technological demands and potential consumption of physically solid by-products, SSF is a promising alternative process in the value-addition of certain types of solid wastes, namely non-toxic, organic solid wastes from the agriculture and food and beverage industries.

Brewery spent grain (BSG) was studied as a substrate for SSF. BSG is of heterogeneous composition, consisting of malted barley [4], maize, wheat and rice [5]. Agamuthu [6] stated that $14 \mathrm{~kg}$ of BSG was generated for every 100 liters of beer produced. The Carlsberg Group [7] stated $15.6 \mathrm{~kg}$ of BSG was generated for every 100 liters of beer produced in both 2003 and 2004.

BSG is sold as a feedstock supplement [8] and was also reported to improve soil quality and yield of egg plant [9], to be suitable for production of xylitol [10] and alcohol [11], to remove heavy metals from industrial pollutants [12], to be suitable in the cultivation of oyster mushrooms [13], to be a source of fiber for consumption [14], to be able to increase the porosity and strength of bricks [15] and to be a suitable feed replacement in crayfish culture [16].

In Malaysia, BSG is under-utilized and is mostly used as cattle feed, in small amounts. This under-utilization is attributed to its high moisture content (causing transportation and storage difficulties), complex composition, the stigma of being labelled a waste material [17] and potential for rapid spoilage [18].

The objective of this study is to analyze the composition of BSG and assess its potential as a substrate for enzyme production by solid-state fermentation.

\section{MATERIALS AND METHODS}

All chemicals were obtained from Sigma, Aldrich, Fluka or BDH Analytical Supplies. All spectrophotometer readings were made using a Hach DR4000 Spectrophotometer (USA). Results are presented as the mean of four replicates with standard deviation. 


\section{Spent grain preparation}

Fresh BSG was provided by Carlsberg Brewery (Malaysia) Ltd. A portion was immediately set aside for chemical analyses while $50 \mathrm{~g}$ was delivered into $500 \mathrm{ml}$ conical flasks, sterilized at $121^{\circ} \mathrm{C}$ for 20 minutes (Arnold and Sons, Basildon Ltd. England) and left to cool.

\section{Moisture content}

The moisture content of fresh BSG was determined by drying fresh BSG in an oven (Memmert, Germany) at $50 \pm 2^{\circ} \mathrm{C}$ for ten days. Once a day, the spent grain was removed, left at room temperature $\left(27 \pm 3^{\circ} \mathrm{C}\right)$ for ten minutes and weighed.

\section{Acid Detergent Fiber, Lignin, Cellulose and Ash [19]}

\section{Acid Detergent Fiber (ADF)}

A known mass of fresh BSG was refluxed (Witeg, Germany) at $90 \pm 5^{\circ} \mathrm{C}$ for 60 minutes in a solution of cetyl tri-methylammonium dissolved in sulfuric acid $\left(\mathrm{H}_{2} \mathrm{SO}_{4}\right)$. The solution was filtered (Advantech Qualitative Filter, Japan, $55 \mathrm{~mm}$ ) and the retained portion was rinsed with distilled water $\left(90^{\circ} \mathrm{C}\right)$ and acetone $\left(4^{\circ} \mathrm{C}\right)$ in tandem twice. The solid remnant was dried (Shellab $1375 \mathrm{FX}, \mathrm{USA}$ ) at $105^{\circ} \mathrm{C}$ for 12 hours. Finally, the solid remnant was removed, left at room temperature for ten minutes and weighed. $\mathrm{ADF}(\%)$ was calculated as the difference between the mass of treated and raw BSG.

\section{Lignin}

BSG similar in mass to the one used in ADF was delivered into a mixture of saturated potassium permanganate and buffer solution (ferric nitrate, argentum nitrate, potassium acetate, glacial acetic acid and tertiary butyl alcohol) and left at room temperature for 90 minutes. Next, the liquid portion was decanted and discarded. A de-mineralizing solution (dehydrate oxalic acid, ethanol, hydrochloric acid and distilled water) was poured onto the solid portion. After 10 minutes, the demineralizing solution was discarded while the solid portion was rinsed with $80 \%$ ethanol and acetone $\left(4^{\circ} \mathrm{C}\right)$ in tandem twice. The solid remnant was weighed and dried in an oven at $105^{\circ} \mathrm{C}$ for 12 hours. Lignin (\%) was calculated as the difference between the mass of the originally treated BSG and treated BSG after drying.

\section{Cellulose}

Cellulose was calculated the difference between the mass of lignin and ADF taken as a percentage of the original mass of BSG used.

\section{Ash}

The solid remnant from lignin analysis of lignin was baked (Wisetherm FH - 05, Korea) at $450^{\circ} \mathrm{C}$ for eight hours. After adequate cooling, the ash was removed from the furnace and weighed. Ash was calculated as the mass of the BSG after baking taken as a percentage of the original mass of BSG used.

\section{Elemental analysis [20]}

A known mass of fresh BSG was refluxed at 90 $\pm 5^{\circ} \mathrm{C}$ for 30 minutes in a mixture of $50 \%$ nitric acid $\left(\mathrm{HNO}_{3}\right)$ and $20 \%$ hydrochloric acid $(\mathrm{HCl})$. After cooling, the mixture was poured into a $100 \mathrm{ml}$ volumetric flask, made to volume with distilled water and left overnight.

Inductively coupled plasma-atomic emission spectrometry (ICP-AES) was used to determine copper, cobalt, calcium, iron, manganese, magnesium, sodium, selenium, silica, phosphorus and sulphur in the mixture.

\section{Total Carbon, Total Nitrogen, Total Protein, Starch and Lipids}

Total Carbon [21]

A known mass of fresh BSG was weighed and baked in a furnace at $400^{\circ} \mathrm{C}$ for 12 hours. At the appropriate time, the remnants were removed from the oven, allowed to cool and weighed again. Total carbon was calculated as the difference between the mass of BSG before and after baking, taken as a percentage of the original mass of BSG used.

\section{Total Nitrogen [22]}

A known mass of fresh BSG was delivered into a mercuric sulfate solution. Potassium sulfate $(0.5 \mathrm{~g}), 1 \mathrm{ml}$ of concentrated sulfuric acid and four pieces of aluminum oxide granules were added. The mixture was refluxed at $90 \pm 5^{\circ} \mathrm{C}$ for 30 minutes and then further refluxed at $60 \pm 5^{\circ} \mathrm{C}$ for 60 minutes or until the mixture turned clear. Next, the mixture was refluxed again at $60 \pm$ $5^{\circ} \mathrm{C}$ for 30 minutes and allowed to sufficiently cool.

The mixture was decanted into a distillation flask and $2 \mathrm{ml}$ of distilled water was used to rinse the inner walls of the flask. Next, $0.2 \mathrm{~g}$ of zinc, $5 \mathrm{ml}$ of $10 \mathrm{~N}$ sodium hydroxide $(\mathrm{NaOH})$ and $10 \mathrm{ml}$ of $0.01428 \mathrm{~N} \mathrm{H}_{2} \mathrm{SO}_{4}$ was added and distillation took place. After distillation, $0.8 \mathrm{ml}$ 
of $0.1 \%$ alizarin red solution was added and mixed gently. The mixture was titrated with $0.01428 \mathrm{~N} \mathrm{NaOH}$ until the mixture became clear. The volume of $0.01428 \mathrm{~N} \mathrm{NaOH}$ used in titration of the mixture was noted.

A blank solution incorporating distilled water instead of BSG was also made and the method was repeated. Total nitrogen was calculated as a percentage of the mass of BSG used in the analysis.

\section{Total Protein}

Total protein was calculated based on formulas adapted from Hiller et al. [22] and AOAC International Methods 930.29 [23] and 991.20 [24].

\section{Starch [25]}

A known mass of fresh BSG was delivered into a test tube and mixed with $5 \mathrm{ml}$ of distilled water. The mixture was heated in a water bath (approximately $100^{\circ} \mathrm{C}$ ) for 15 minutes, removed and allowed to cool. Next, $5 \mathrm{ml}$ of $60 \%$ perchloric acid $\left(\mathrm{HClO}_{4}\right)$ was rapidly mixed into the solution. The BSG was manually pressed against the inner part of the tube with a glass rod every three minutes for 30 minutes. The mixture was decanted into a volumetric flask filled with $100 \mathrm{ml}$ of distilled water and $3 \mathrm{ml}$ of $5 \%$ uranyl acetate solution was added. The mixture was centrifuged (Heraeus Christ, Germany) and $10 \mathrm{ml}$ of supernatant was removed and delivered into a clean test tube. The following was added: $0.1 \mathrm{~g}$ of kieselguhr, $5 \mathrm{ml}$ of $20 \% \mathrm{NaCl}$ solution and $2 \mathrm{ml}$ of iodinepotassium iodide solution. The mixture was thoroughly mixed and left for 12 hours.

Next, $5 \mathrm{ml}$ of an alcohol-sodium chloride solution was added. The mixture was centrifuged at $3000 \mathrm{rpm}$ for 15 minutes. The supernatant was gently removed and $2 \mathrm{ml}$ of an alcohol-sodium hydroxide solution was added on to the precipitate. The mixture was gently tapped and shaken until the precipitate lost its blue colour.

The inner walls of the test tube were washed with $5 \mathrm{ml}$ of the alcohol- $\mathrm{NaCl}$ solution. The mixture was centrifuged and $5 \mathrm{ml}$ of alcohol$\mathrm{NaCl}$ and $2 \mathrm{ml}$ of $0.7 \mathrm{M} \mathrm{HCl}$ solution was added to the solution to precipitate the starch. The mixture was placed in a water bath at approximately $100^{\circ} \mathrm{C}$ for 150 minutes and later allowed to cool.

After adequate cooling, the mixture was poured into a $25 \mathrm{ml}$ volumetric flask. Two drops each of phenol red, $1 \mathrm{M} \mathrm{NaOH}$ and $0.05 \mathrm{M}$ oxalic acid were added. Distilled water was also added until the volume was made to $25 \mathrm{ml}$. Five milliliters was removed and mixed with $5 \mathrm{ml}$ of a somogyi reagent. The mixture was heated in a water bath at approximately $100^{\circ} \mathrm{C}$ for 15 minutes. At the appropriate time, tubes were removed from the water bath and left to cool.

Next, $1 \mathrm{ml} 2.5 \%$ iodine-potassium iodide solution and $3 \mathrm{ml}$ of $0.75 \mathrm{M} \mathrm{H}_{2} \mathrm{SO}_{4}$ was mixed into the solution which was titrated with $0.0055 \mathrm{M} \mathrm{Na} \mathrm{Na}_{2} \mathrm{~S}_{2} \mathrm{O}_{3}$, with the starch indicator added just before the end point was reached.

Blank solution incorporating distilled water instead of BSG was also made and the method was repeated. Starch (\%) was calculated as a percentage of the mass of BSG used in the analysis.

\section{Lipids [26]}

Fresh BSG was ground in an abrasive concrete pot and a known mass of ground BSG was weighed in a glass tube. An extraction solution was prepared by mixing propanol, hexane and distilled water and $5 \mathrm{ml}$ was added to the ground BSG sample. Next, the mixture was incubated at $60^{\circ} \mathrm{C}$ for 15 minutes and centrifuged at 5000 rpm for 15 minutes. The supernatant was discarded. This procedure was repeated twice and both times, the precipitate was mixed with $5 \mathrm{ml}$ of the extraction solution. Lipid (\%) was calculated as a percentage of the mass of BSG used in the analysis.

\section{Fungi preparation and inoculation}

In this study, nine fungi were studied: Aspergillus niger, Penicillium chrysogenum, Rhizopus arrhizus, Trichoderma viridae, Trametes hirsuta, Pycnoporus sanguineus, Pleurotus sajor-caju, Schizophyllum commune and Ganoderma tsugae.

Each fungus was maintained on malt extract agar (Oxoid, England) plates and incubated at $28 \pm 2^{\circ} \mathrm{C}$ for seven days. Four agar plugs (each $\pm 8 \mathrm{~mm}$ ) with its mycelia, were removed from the periphery of each seven-day old MEA plate and used as the inocula.

The inocula were delivered directly into each flask containing the cooled, sterile spent grain. Negative control was conducted by leaving sterile spent grain flasks un-inoculated. The mouth of each flask was covered with a cotton stopper. Four replicates were made. Incubation was done at $28 \pm 2{ }^{\circ} \mathrm{C}$ for seven days. 


\section{Extraction}

A volume of $400 \mathrm{ml}$ of distilled water was poured into each flask. The flasks underwent mixing by mechanical shaking at $180 \mathrm{rpm}$ for 60 minutes at $30^{\circ} \mathrm{C}$ (Series 25 Incubator Shaker, New Brunswick Scientific, USA). Further physical extraction was done by centrifugation (Heraeus Christ, Germany) at $4000 \mathrm{rpm}$ for 20 minutes at $30^{\circ} \mathrm{C}$. The supernatant was used as the enzyme extract.

\section{Determination of enzyme activity (expressed in $\mathrm{U} / \mathrm{ml}$ )}

Laccase [27, 28]

First, $100 \mu \mathrm{l} \mathrm{ml}$ of the enzyme extract was mixed with $2.9 \mathrm{ml}$ Syringaldazine $(20 \mu \mathrm{M})$ and then with $50 \mu \mathrm{l}$ of sodium phosphate $(50 \mathrm{mM})$. Absorbance was read at $525 \mathrm{~nm}$ and enzyme activity was calculated.

\section{Lignin peroxidase [27, 29]}

A volume of $500 \mu \mathrm{l}$ of the enzyme extract was mixed with $1 \mathrm{ml}$ sodium tartarate buffer (100 mmol, $\mathrm{pH}$ 3), $500 \mu \mathrm{l}$ of Veratryl Alcohol (2 mmol) and $500 \mu \mathrm{l}$ of hydrogen peroxide $(0.5$ mmol). Absorbance was read at $310 \mathrm{~nm}$. For standardization purposes, veratryl alcohol was used and the enzyme activity was calculated.

\section{Xylanase [30]}

After centrifugation, $200 \mu \mathrm{l}$ of the enzyme extract was mixed with $1.8 \mathrm{ml}$ of a $1 \%$ oat xylan solution (prepared in $0.05 \mathrm{M}$ sodium citrate buffer, $\mathrm{pH}$ 6.5). The mixture was incubated at $50^{\circ} \mathrm{C}$ for 5 minutes. Next, $3 \mathrm{ml}$ of $3,5-$ dinitrosalicylic acid was added and the mixture placed in a water bath at $60^{\circ} \mathrm{C}$ for 15 minutes and later allowed to cool. Absorbance was read at $540 \mathrm{~nm}$. For standardization purposes, xylose was used and the enzyme activity was calculated.

\section{Amylase [31]}

First, $150 \mu \mathrm{l}$ of the enzyme extract was mixed with $200 \mu \mathrm{l}$ of $1 \%$ soluble starch (prepared in $0.1 \mathrm{M}$ phosphate buffer). The mixture was incubated at $37^{\circ} \mathrm{C}$ for 25 minutes. Then, $400 \mu \mathrm{l}$ of 3, 5 - dinitrosalicylic acid was mixed in and the mixture was placed in a water bath at $60^{\circ} \mathrm{C}$ for 5 minutes and later allowed to cool. Next, 8 $\mathrm{ml}$ of distilled water was added and absorbance was read at $489 \mathrm{~nm}$. For standardization purposes, D-glucose was used and the enzyme activity was calculated.
Carboxymethyl cellulase (CMCase) [32, 33] First, $400 \mu \mathrm{l} \mathrm{ml}$ of the enzyme extract was mixed with $1.6 \mathrm{ml}$ of a $1 \%$ carboxymethylcellulose solution (prepared with a $40 \mathrm{mM}$ sodium acetate buffer solution). The mixture was incubated at $37^{\circ} \mathrm{C}$ for 25 minutes. Then, $400 \mu$ of 3, 5 - dinitrosalicylic acid was added and the mixture placed in a water bath at $60^{\circ} \mathrm{C}$ for 5 minutes and later allowed to cool. Next, $8 \mathrm{ml}$ distilled water was added and absorbance was read at $489 \mathrm{~nm}$. For standardization purposes, D-glucose was also used and the enzyme activity was calculated.

\section{Protease [34]}

First, $30 \mu \mathrm{l}$ of enzyme extract was mixed with $500 \mu \mathrm{l}$ of casein and $470 \mu \mathrm{l}$ of phosphate buffer $(0.1 \mathrm{M})$. The solution was incubated at $60^{\circ} \mathrm{C}$ for 10 minutes. A volume of $1 \mathrm{ml}$ tricholoroacetic acid $(10 \%)$ was added and the mixture was centrifuged for 15 minutes at $4^{\circ} \mathrm{C}$.

Next, $5 \mathrm{ml}$ of sodium carbonate $(0.44 \mathrm{M})$ and 1 $\mathrm{ml}$ of Folin-Ciocalteau reagent is added to the supernatant. This mixture was incubated at $30^{\circ} \mathrm{C}$ for 30 minutes. Absorbance was read at $660 \mathrm{~nm}$. For standardization purposes, LTyrosine was also used and the enzyme activity was calculated.

\section{Tannase [35]}

First, $50 \mu \mathrm{l} \mathrm{ml}$ of enzyme extract was mixed with $300 \mu \mathrm{lml}$ of a $0.5 \%$ tannic acid solution. Next, $3 \mathrm{ml}$ of Bovine Serum Albumin solution $(1 \mathrm{mg} / \mathrm{ml}$, prepared in $0.17 \mathrm{M}$ sodium chloride buffer solution) was added. The mixture was centrifuged at $7000 \mathrm{rpm}$ for 10 minutes at $4^{\circ} \mathrm{C}$. Then, $3 \mathrm{ml}$ Sodium Dodecyl Sulfate (SDS, 1\%) triethanolamine solution was added, as was $1 \mathrm{ml}$ of Ferum Chloride $\left(\mathrm{FeCl}_{3}\right)$ solution.

The mixture was left for 15 minutes. Absorbance was read at $530 \mathrm{~nm}$. For standardization purposes, Gallic Acid was also used and the enzyme activity was calculated.

\section{RESULTS AND DISCUSSION}

The $73 \%$ moisture content of BSG (Table 1) is in accordance with the range stated by Mussatto et al. [36]. Due to its high moisture content, BSG can spoil within seven to ten days [37] in hot climates. In this study, un-sterilized BSG stored in sealed, thick polypropylene bags could only be stored at $4^{\circ} \mathrm{C}$ for approximately 14 days before putrifying. 
Table 1: Moisture content of brewery spent grain

\begin{tabular}{|l|c|c|}
\hline \multirow{3}{*}{ Spent } & Mean Moisture & \\
\cline { 2 - 3 } Grain & 72.616755 & Standard Deviation \\
\hline
\end{tabular}

BSG consists of approximately 57\% lignin, 40\% cellulose and 23\% ADF (Table 2). There were high amounts of calcium, magnesium, silica and

Table 2: Composition of fresh BSG

\begin{tabular}{|l|c|c|}
\hline \multicolumn{1}{|c|}{ Parameter } & Mean & Standard Deviation \\
\hline Acid Detergent Fibre (\% per gram of spent & 23.294280 & 0 \\
grain) & 56.744022 & 9.378141 \\
Lignin (\% per gram of spent grain) & 40.203778 & 14.709977 \\
Cellulose (\% per gram of spent grain) & 2.269503 & 0.761340 \\
Ash (\% per gram of spent grain) & 6.410000 & 0.311127 \\
Protein (\% per gram of spent grain) & 2.495000 & 0.106066 \\
Lipids (\% per gram of spent grain) & 0.280000 & 0.056569 \\
Starch (\% per gram of spent grain) & 35.610000 & 0.282843 \\
Total Carbon (\%) & 1.025000 & 0.049497 \\
Total Nitrogen (\%) & & \\
\hline
\end{tabular}

Table 3: Elemental composition of fresh BSG

\begin{tabular}{|l|c|c|c|}
\hline \multicolumn{1}{|c|}{ Element } & Detection Limit & Mean Concentration & Standard Deviation \\
\hline Copper (ppm) & 0.01 & 2.5 & 0.7 \\
Cobalt (ppm) & 0.02 & 0 & 0 \\
Calcium (ppm) & 0.09 & 1038.5 & 3.5 \\
Iron (ppm) & 0.02 & 63.5 & 14.8 \\
Manganese (ppm) & 0.01 & 9.5 & 0.7 \\
Magnesium (ppm) & 0.01 & 687.5 & 108.2 \\
Sodium (ppm) & 0.03 & 60.5 & 3.5 \\
Selenium (ppm) & 0.01 & 6.0 & 0 \\
Silica (ppm) & 0.01 & 242.0 & 82.0 \\
Phosphorus (ppm) & 0.03 & 1977.0 & 66.5 \\
Sulphur (ppm) & 0.01 & 8.5 & 0.7 \\
\hline
\end{tabular}


By virtue of being a by-product from a compendium of various grains, the exact formulation of BSG could vary according to the brewery and the production region. Flavour requirements of the beer and grain logistics often take precedence and affect grain composition, which affects BSG characteristics. Because of the variability, there is a value range for data of several BSG characteristics in published literature. Table 4 illustrates the differences of several major BSG characteristics.

Table 4: Value ranges of data reported for several BSG characteristics

\begin{tabular}{|c|c|c|}
\hline Parameter & $\begin{array}{l}\text { Characteristics } \\
\text { (\% of BSG weight) }\end{array}$ & References \\
\hline Protein & $\begin{array}{c}6 \\
15 \\
22-27 \\
31\end{array}$ & $\begin{array}{l}\text { Current study } \\
\text { Mussatto and Roberto [38] } \\
\text { Santos et al. [39] } \\
\text { Prentice and Refsguard [40] }\end{array}$ \\
\hline Lignin & $\begin{array}{l}16 \\
27 \\
57\end{array}$ & $\begin{array}{l}\text { Prentice and Refsguard [40] } \\
\text { Mussatto and Roberto [38] } \\
\text { Current study }\end{array}$ \\
\hline Cellulose & $\begin{array}{l}9 \\
25 \\
40\end{array}$ & $\begin{array}{l}\text { Prentice and Refsguard [40] } \\
\text { Mussatto et al. [36] } \\
\text { Current study }\end{array}$ \\
\hline
\end{tabular}

Huige [41] attributed the differences in BSG characteristics to the time of grain harvest and the physical/chemical conditions of malting and mashing operations.

In a brewery, grains undergo steeping and germination to activate starch degrading enzymes which will hydrolyze the endosperm into maltose, dextrins and amino acids during the mashing process. The sugars and amino acids will be diverted away for alcohol production, leaving BSG to be disposed. These procedures could explain the starch content being detectable at only trace quantities [36]. Copper, manganese, selenium and sulphur were also detected in trace quantities.

There is high concentration of lignin in BSG. Lignin is insoluble and consists of carbon chains held together by carbon-carbon and ether bonds. The lignin polymer engulfs microfibrils of the secondary wall which consists of cellulose [42].
In BSG, due to the low starch concentration and lignin decreasing cellulose accessibility [43], lignin would have to temporarily assume the primary nutrient role for fungi.

The fungi in this study spanned three phyla: Ascomycota, Basidiomycota and Zygomycota. All the fungi studied could colonize sterile BSG. In general, fungal macrostructures were visible within the third day of incubation. Within five days, complete colonization of BSG was observed for all fungi. Taking $A$. niger and $R$. arrhizus as examples, the fermented BSG could not be shaken within the conical flasks and mycelia with black (A. niger) or green $(R$. arrhizus) sporangia were visible. This was also the case with $P$. chrysogenum and white filaments appearing similar to cotton completely engulfed the BSG.

Fungi are suitable process microorganisms for $\mathrm{SSF}$ as SSF closely resembles the natural 


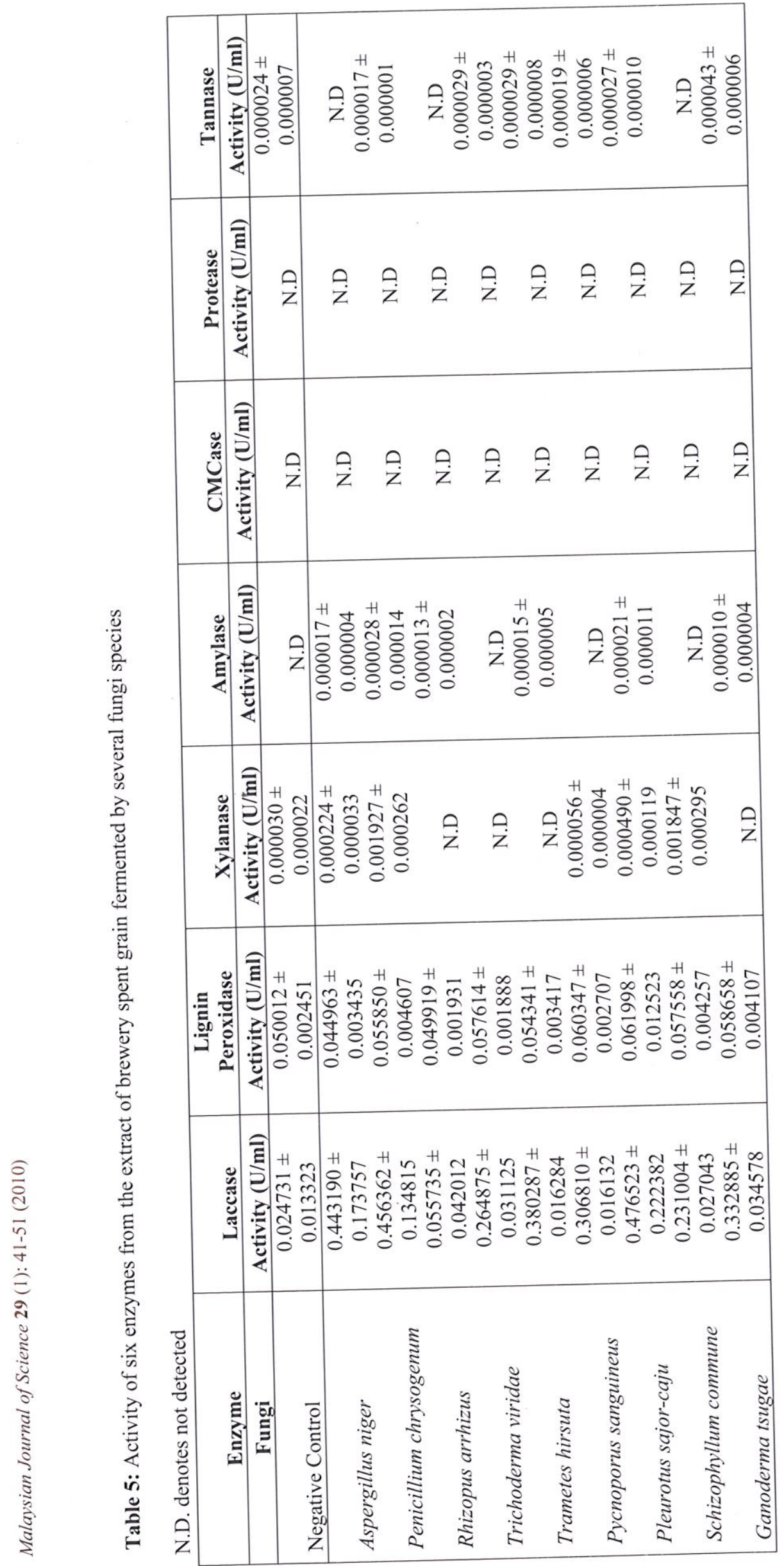


environment of fungi [44] - higher temperatures, low water availability and high osmotic pressure [45]. SSF encourages deep contact between the substrate and fungi [46], allowing mycelia to rapidly colonize the solid substrate and reduces the need for absolute aseptic conditions.

All fungi showed positive enzyme activity (Table 5) but laccase was higher than its negative blank (by $100 \%-1700 \%$ ) and other enzymes studied (by $10^{1}-10^{4}$ ). This observation was similar for every fungus studied.

Laccase is non-specific in its activity [47]. It allows fungi to completely degrade lignin by catalyzing the oxidation of aromatic hydrogen, with decarboxylation and demethylation of phenolic and methoxyphenolic acids, resulting in the reduction of oxygen to water [48]. Carbon dioxide [49] is also formed.

The Basidiomycota $P$. sajor-caju showed highest overall laccase activity $(0.477 \pm 0.222$ $\mathrm{U} / \mathrm{ml})$. Both members of the Deutromycota, $A$. niger and $P$. chrysogenum showed similar activity $(0.443190 \pm 0.173757 \mathrm{U} / \mathrm{ml}$ and $0.456362 \pm 0.134815 \mathrm{U} / \mathrm{ml}$, respectively). Enzyme attivities for the sole fungi of the Zygomycota, $R$. arrhizus were generally the lowest.

Fungi in this study appear to preferentially utilize laccase instead of lignin peroxidase (LiP). This is similar to the findings of Fenice et al. [50] who reported dominant activity of laccase compared $\mathrm{MnP}$ in strains of the Basidiomycota Panus tigrinus in both SSF and submerged fermentation; while Reddy et al. [51] also reported higher activity of laccase compared to LiP in SSF of banana wastes by Pleurotus ostreatus and P. sajor-caju.

Laccase would be utilized more as it is produced constitutively and a laccase-based oxidation system would require less induction compared to lignin peroxidase [52]. The fungi studied would secrete laccase extracellularly to hydrolyze lignin before absorbing the simpler materials as nutrients.

In BSG, the high percentage of lignin (57\% per gram), coupled with low percentage of starch $(<1)$ would explain the higher activity of laccase compared to other enzymes in this study. There were neither chemical inducers nor supplements added to the BSG cultures.

\section{CONCLUSION}

Basidiomycota $P$. sajor-caju fungi gave consistent output of extra-cellular enzyme at significant concentration compared to other 8 fungi. Laccase output was the most promising compared to the six enzymes tested. Brewery spent grain can be considered a potential substrate for the fungal production of laccase.

\section{ACKNOWLEDGEMENTS}

The authors gratefully thank Carlsberg Brewery (Malaysia) Ltd. for graciously providing the spent grain utilized in this study. The research was funded by the University of Malaya Research Grant P0129/2006C.

\section{REFERENCES}

1. Pandey A, Azmi W, Singh J, Banerjee UC. Types of fermentation and factors affecting it. In: Joshi VK, Pandey A editors. Biotechnology: Food Fermentation. New Delhi: Educational Publishers; 1999. p. 383 $-426$.

2. Pandey A. Solid-state fermentation. Biochemical Engineering Journal 2003; 13: $81-84$.

3. Mitchell DA, Berovic M, Krieger N. What is Solid-State Fermentation? In: Mitchell DA, Krieger N, Berovic M editors. SolidState Fermentation Bioreactors: Fundamentals of Design and Operation $\left(1^{\text {st }}\right.$ Edition). Springer; 2006. p. 1.

4. Celus I, Brijs K, Delcour JA. The effects of malting and mashing on barley protein extractability. Journal of Cereal Science 2006; 44: 203 - 211.

5. Tang Z, Cenkowski S, Muir WE. Modelling superheated-steam drying of a fixed bed of brewers spent grain. Biosystems Engineering 2004; 87 (1): 67 77.

6. Agamuthu P. Solid Waste: Principles and Management. Kuala Lumpur: University of Malaya Press; 2001. p $174-179$.

7. Carlsberg Group. Environmental Report 2003 and 2004. Downloaded from the Carlsberg Group's website (21 December 2007); 2005. p. 8.

8. International Finance Corporation of the World Bank Group. Environmental, Health and Safety Guidelines for Breweries. Downloaded from the IFC's website (25 December 2007); 2007. p. 6.

9. Moyin-Jesu EI. Use of plant residues for improving soil fertility, pod nutrients, root 
growth and pod weight of okra (Abelmoschus esculantum L). Bioresource Technology 2007; 98: 2057 - 2064.

10. Mussatto SI, Dragone G, Roberto IC. Influence of the toxic compounds present in brewer's spent grain hemicellulosic hydrolysate on xylose to xylitol bioconversion by Candida guilliermondii. Process Biochemistry 2005; 40: 3801 3806.

11. Kopsahelis N, Agouridis N, Bekatorou A, Kanellaki M. Comparative study of spent grains and delignified spent grains as yeast supports for alcohol production from molasses. Bioresource Technology 2007; 98: $1440-1447$.

12. Low KS, Lee CK, Liew SC. Sorption of cadmium and lead from aqueous solutions by spent grain. Process Biochemistry 2000; $36(1-2): 59-64$.

13. Wang D, Sakoda A, Suzuki M. Biological efficiency and nutritional value of Pleurotus ostreatus cultivated on spent beer grain. Bioresource Technology 2001; 78: $293-300$.

14. Carvalheiro F, Esteves MP, Parajo JC, Pereira H, Girio FM. Production of oligosaccharides by autohydrolysis of brewery's - spent grain. Bioresource Technology 91: $93-100$.

15. Russ W, Mortel H, Meyer-Pittroff R. Application of spent grains to increase porosity in bricks. Construction and Building Materials 2005; 19 (2): 117 - 126.

16. Muzinic LA, Thompson KR, Morris A, Webster CD, Rouse DB, Manomaitis L. Partial and total replacement of fish meal with soybean meal and brewer's grains with yeast in practical diets for Australian Red Claw Crayfish Cherax quadricarinatus. Aquaculture 2004; 230: 359 - 376.

17. Khidzir KM, Agamuthu P, Abdullah N. Utilizing solid waste from a brewery as a substrate in enzyme production. In: Proceedings of the International Solid Waste Association Annual Congress 2007. p. 17.

18. Douwenga R, de Boks PA., Luyben KCAM. Degradation of suspended proteins in an anaerobic rotating bed contactor. Biotechnology Letters 1988; 10 (4): 267 272.

19. Van Soest P, Wine RH. Determination of lignin and cellulose in acid detergent fibre with permanganate. Journal of the Association of Official Analytical Chemists $1968 ; 51: 780-785$.
20. United States Environmental Protection Agency. U.S. EPA Drinking Water Methods for Chemical Contaminants (200.7 Rev 4.4): Metals and Trace Elements by ICP/Atomic Emission Spectrometry. Methods for the Determination of Metals in Environmental Samples Supplement 1 (EPA/600/R-94/111). Downloaded from the website of the Department of Environmental Conservation, Alaska, USA (20 April 2008); 1994. p. 4 - 22.

21. Schumacher BA. Methods for the Determination of Total Organic Carbon (TOC) in Soils and Sediments. Downloaded from the website of the United States Environmental Protection Agency, Environmental Sciences Division $\left(24^{\text {th }}\right.$ April 2008); 2002. p. 6 - 12.

22. Hiller A, Plazin J, Van Slyke DD. A study of conditions for Kjeldahl determination of nitrogen in proteins. Journal of Biological Chemistry 1948; 176: $1401-1420$.

23. AOAC International. AOAC Official Method 930.29: Protein in Dried Milk. Downloaded from the website of AOAC International (15 May 2008); 2006. p. 1.

24. AOAC International. AOAC Official Method 991.20: Total Nitrogen in Milk. Downloaded from the website of AOAC International (15 May 2008); 2006. p. 1- 2.

25. AOAC International. AOAC Official Method 948.02: Starch in Plants (Titrimetric Method). Downloaded from the website of AOAC International (15 May 2008); 2006. p. 1.

26. Markham JE, Li J, Cahoon EB, Jaworski JG. Separation and identification of major plant sphingolipid classes from leaves. Journal of Biological Chemistry 2006; 281 (32): $22684-22694$.

27. Singh AD, Vikineswary S, Abdullah N. Extraction of enzymes from spent compost of Pleurotus sajor-caju and its potential use for decolourization of synthetic dyes. Malaysian Journal of Science 2002; 21 : 1 8.

28. Saito T, Hong $\mathrm{P}$, Kato $\mathrm{K}$, Okazaki M, Inagaki $\mathrm{H}$, Maeda $\mathrm{S}$, Yokogawa $\mathrm{Y}$. Purification and characterization of an extracellular laccase of a fungus (family Chaetomiaceae) isolated from soil. Enzyme and Microbial Technology 2003; 33 (4): $520-526$.

29. Arora DS, Gill PK. Comparison of two assay procedures for lignin peroxidase. Enzyme and Microbial Technology 2001; 28: $602-605$. 
30. Bailey MJ, Biely P, Poutanen K. Laboratory testing of methods of assay of xylanase activity. Journal of Biotechnology 1992; 23: $257-270$.

31. Bernfeld P. Enzymes of carbohydrate metabolism; Amylases, alpha and beta. Methods in Enzymology 1955; 1: 149 158.

32. Yamane Y, Fujita J, Shimizu R, Hiyoshi A, Fukuda H, Kizaki Y, Wakabayashi S. Production of cellulose and xylan degrading enzymes by a Koji mold, Aspergillus oryzae, and their contribution to the maceration of rice endosperm cell wall. Journal of Bioscience and Bioengineering 2002; 93 (1): $9-14$.

33. Silva D, Tokuioshi K, da Silva Martins E, Da Silva R, Gomes E. Production of pectinase by solid-state fermentation with Penicillium viridicatum RFC3. Process Biochemistry 2005; 40 (8): 2885 - 2889.

34. Sandhya C, Sumantha A, Szakacs G, Pandey A. Comparative evaluation of neutral protease production by Aspergillus oryzae in submerged and solid state fermentation. Process Biochemistry 2005; 40: 2689 - 2694

35. Mondal KC, Banarjee C, Jana M, Pati BR. Colorimetric assay methods for the determination of tannin acyl hydrolase activity. Analytical Biochemistry 2001; 295, 168 - 171 .

36. Mussatto SI, Dragone G, Roberto IC. Brewers' spent grain: generation, characteristics and potential applications. Journal of Cereal Science 2006; 43 (1), 1 14.

37. Food and Agriculture Organization of the United Nations. Animal Feed Resources Information System. Accessed on the FAO website (23 ${ }^{\text {rd }}$ January 2008); 2008.

38. Mussatto SI, Roberto IC. Acid hydrolysis and fermentation of brewers' spent grain to produce xylitol. Journal of the Science of Food and Agriculture 2005; 85 (14): 2453 2460 .

39. Santos M, Jimenez JJ, Bartolome B, Gomez-Cordoves C, del Nozal MJ. Variability of brewer's spent grain within a brewery. Food Chemistry 2003; 80: 17 21.

40. Prentice N, Refsguard JM. Enzymatic hydrolysis of brewers' spent grain. Journal of the American Society of Brewing Chemists 1978; 36: $196-200$.

41. Huige NJ. Brewery by-products and effluents. In: Hardwick, W. A. (Ed.),
Handbook of Brewing. New York: Marcel Dekker; 1994. p. $501-550$.

42. Cullen D, Kersten PJ. Enzymology and molecular biology of lignin degradation. In: Brambl R, Marzluf GA editors, Biochemistry and Molecular Biology $\left(2^{\text {nd }}\right.$ Edition). Berlin-Heidelberg: SpringerVerlag; 2004. p. 249.

43. Xiros C, Topakas E, Katapodis P, Christakopoulos P. Evaluation of Fusarium oxysporum as an enzyme factory for the hydrolysis of brewer's spent grain with improved biodegradability for ethanol production. Industrial Crops and Products (in press); doi:10.1016/j.indcrop.2008.02.004.

44. Holker U, Lenz J. Solid-state fermentation - Are there any biotechnological advantages? Current Opinion in Microbiology 2005; 8: $301-306$.

45. Raimbault M. General and microbiological aspects of solid substrate fermentation. Electronic Journal of Biotechnology 1998; 1: $1-20$.

46. Holker U, Hofer M, Lenz J. Biotechnological advantages of laboratoryscale solid-state fermentation with fungi. Applied Microbiology and Biotechnology 2004; 64: 175 - 186.

47. Couto SR, Toca-Herrera JL. Laccase production at reactor scale by filamentous fungi. Biotechnology Advances 2007; 25: $558-569$.

48. Wesenberg D, Kyriakides I, Agathos SN. White-rot fungi and their enzymes for the treatment of industrial dye effluents. Biotechnology Advances 2003; 22: 161 187.

49. Have RT, Teunissen JM. Oxidative mechanisms involved in lignin degradation by white-rot fungi. Chemical Review 2001; 10: $3397-3413$.

50. Fenice M, Sermanni GG, Federici F, D'Annibale A. Submerged and solid-state production of laccase and Mn-peroxidase by Panus tigrinus on olive mill wastewaterbased media. Journal of Biotechnology 2003; 100: 77 - 85 .

51. Reddy GV, Babu PR, Komaraiah P, Roy, KRRM, Kothari IL. Utilization of banana waste for the production of lignolytic and cellulolytic enzymes by solid substrate fermentation using two Pleurotus species ( $P$. ostreatus and $P$. sajor-caju). Process Biochemistry 2003; 38: 1457 - 1462.

52. Pointing SB, Vrijmoed LLP. Decolorization of azo and triphenylmethane dyes by Pycnoporus sanguineus producing laccase 
as the sole phenoloxidase. World Journal of Microbiology and Biotechnology 2000; 16:

$317-318$. 